National Research University Higher School of Economics, Moscow, Russian Federation ORCID 0000-0002-9471-0091

\title{
Polish Medicine in the Russian Empire in the First Third of the $19^{\text {th }}$ Century
}

An official's complaint about a Polish private doctor who treated his children for scarlet fever in 1827 gave rise to a unique document - a description of the treatment process and of the doctor's interaction with patients, pharmacists, and Russian authorities. Such evidence is rarely found in the Russian archives. Since private doctors did not report to the officials, their testimonies, as a rule, are not preserved in the state archives. A text found in the archives of the Vilna Medical Board stimulated the authors of the present article to investigate the state of medical care and medical culture of the Polish population that became part of the Russian Empire after the Third Partition of Poland. Vishlenkova and Zatravkin have found that, unlike the rest of the Empire, a rather dense network of private medical care existed in Vilna province until the 1830s, and the level of scientific medical culture of the patients allowed them to establish control over treatment.

Keywords: Russian Empire, Vilna province, history of medicine, scientific medical culture, private medicine, history of science

Słowa kluczowe: Cesarstwo Rosyjskie, gubernia wileńska, historia medycyny, naukowa kultura medyczna, medycyna prywatna, historia nauki

The territories acquired by the Russian Empire as a result of the partitions of Poland (1797) retained the old social structure and infrastructure of city life for a long time in the new state, being only weakly subordinated to the Russian bureaucracy. This statement could be confirmed by the study of the market of medical services in Vilna (Vilno, Wilna, Wilno, now Vilnius) governorate. At that time the demand and satisfaction of the need for medical care depended directly upon the living standards of the population and on the development of the state, its administrative and financial resources. In this regard, the 
former Polish lands and internal governorates of the Russian Empire were in stark contrast with each other.

The authors of medical-topographical descriptions of the 1830s were skeptical of the demand of Russians for the services of medical scientists. They reported on the unwillingness of ordinary people to go to the doctors, not to mention, pay for their services. As a rule, only educated and prosperous segments of the population, at most $10 \%$ at the beginning of the $19^{\text {th }}$ century, sought the assistance from university-trained doctors. ${ }^{1}$ The sufficiency of scientific doctors in Russia was also painful. ${ }^{2}$ In the $18^{\text {th }}$ century, the Empire provided itself with doctors through international hiring and medical mobility. This practice continued until 1828. The Medico-Surgical Academy in St. Petersburg and its branch in Moscow created at the beginning of the $19^{\text {th }}$ century, as well as the divisions of medical sciences at the universities in Moscow, Kharkov, Dorpat and Kazan all together provided less than a hundred graduates per year, yet increasing the number of trained doctors every year; most of them were engaged by the military department. Researchers report disastrously poor sufficiency in licensed physicians (i.e., those who passed the state examinations). Until the 1830 s, the ratio was less than one doctor per 10,000 inhabitants. ${ }^{3}$ In absolute figures, the picture was as follows: in 1809, the Russian medical list included 2478 physicians. In comparison, in Britain, with much smaller area and population, the Medical Register of 1783 gave the names and addresses of 3120 physicians. ${ }^{4}$

The Russian Empire created its system of state medicine at the end of the $18^{\text {th }}$ century. Medical councils, of three physicians each, were instituted in all 34 governorates. The medical control over the counties should be exercised by 'county doctors'; the shortage of whom was constantly visible. In 1820, there were only 11 state doctors and 5 private practitioners all over the Voronezh governorate and 12 and 8 respectively throughout the Tambov governorate. ${ }^{5}$ According to the memorial notes of the civil general staff doctor A.A. Crichton, this very meager medical staff was supplied beggarly and overloaded with administrative affairs: inspections of draftees and corpses, participation in court proceedings, statistical reporting, monitoring of markets, city cemeteries and drinking water sources, billeted soldiery and hospitals. ${ }^{6}$

The Vilna Governorate, inhabited by Poles, Lithuanians and Jews, was medically prosperous, when compared to the central governorates of Russia. In 1828, its residents were served by 207 approved medical persons (162 private and 45 public): 45 private practitioners, 104 private apprentice physicians, 13 private midwives, 14 county doctors, 19 state apprentice physicians, and 12 state midwives. ${ }^{7}$ But to an even greater degree, the relative

1 E. Vishlenkova, Mediko-biologicheskie ob"yasneniya sotsial'nyh problem Rossii (vtoraya tret' XIX veka), [in:] Istoriya $i$ istoricheskaya pamyat': Mezhvuz. sb. nauch. tr., vol. 4, ed. by A. Gladyshev, Saratov 2011, p. 37-66.

2 E. Vishlenkova, The State of Health: Balancing Power, Resources, and Expertise and the Birth of the Medical Profession in the Russian Empire, "Ab Imperio" 2016, no 3, p. 39-75.

3 S. Zatravkin, V. Shepin, V. Oleinikova, Obespechennost' vrachami naseleniya Rossiiskoi Imperii v XIX - nachale $X X$ veka, "Problemy sotsial'noj gigieny, zdravoohraneniya i istorii meditsiny" 2017, no 4, p. 236-239; On the allocation of physicians: D. Sambuk, Wächter der Gesundheit. Staat und lokale Gesellschaften beim Aufbau des Medizinalwesens im Russischen Reich 1762-1831, Köln 2015, s. 164-165.

4 J. Lane, A Social History of Medicine. Health, healing and disease in England, 1750-1950, London, New York 2001, p. 15.

5 D. Sambuk, op. cit., s. 164-165.

6 RGIA, f. 745, op. 3, d. 8, p. 5r.

7 LVIA, f. 564 , ap. 1, b. 21, p. 237. 
medical well-being of this region is evidenced by our study of the functioning of the local medical market.

It is difficult for the historians of the Russian Empire to conduct such research. The imperial archives preserved mainly the evidence of the state structures activities. Accordingly, decrees, statistics on patients and hospitals, reports on the activities of educational and medical institutions, instructions on measures to combat epidemics, results of examinations of corpses, recruits and madmen, and records of meetings of medical officials were deposited there. ${ }^{8}$ So according to the practice of those days, the stories of medical manipulations and the doctor's relationship with the patient were recorded not in reports and protocols, but in ego-documents (many of which refer to memory texts), as well as in 'case histories' and 'mournful lists'. These texts were kept in hospitals either temporarily (while the patient was in an infirmary, clinic or hospital), or in the home archives of doctors. In the state archives, rare examples of such texts were sent either accidentally (for example, used as an excuse for the tragic outcome of treatment), or when a personal archive was transferred by the descendants of an eminent doctor. Consequently, the reconstruction of medical interactions involves the identification of inclusions in genre-foreign texts (for example, in reports, recommendations, reviews, meeting minutes).

In this regard, the Russian situation is quite radically different from the German or British, where the archives of craft guilds, including corporations of surgeons, have been preserved. Therefore, historians of the Kingdom of Prussia and the Austrian and British Empires investigate not only the issues of medicine management and great names, but also the medical market, the conditions of its functioning, the level of payment for medical services, knowledge of provincial doctors and patients, their relationships. ${ }^{9}$ Such publications let them study 'medicine from the bottom' to examine the patients' view of doctors, their behavior during an illness, their attitude (possibly negative) to medical care, and their cultural hierarchies of diseases.

As a result of our work at the Lithuanian State Historical Archive (Lietuvos valstybès istorijos archyvas, LVIA), we found several texts that recorded thoroughly the treatment and interaction of Polish patients with their family doctor in 1827 in Kowno (also Kowna, Kowen; present-day Kaunas, then the capital of the county in the Vilna governorate). Their creation was provoked by a written complaint of the Polish nobleman Ivan Osipovich Blazhevich, employed in the Russian service, who accused the private practitioner,

8 Z. Gatina, Gde iskat' dissertatsionnye dela russkih vrachei, ili Osobennosti arhivirovaniya deloproizvodstva meditsinskih fakul'tetov, [in:] Biografii universitetskih arhivov, ed. by E. Vishlenkova, V. Parsamov, K. Ilina, Moscow 2011, p. 102-113; R. Ivanova, Protokoly zasedanij meditsinskogo fakul'teta Kazanskogo universiteta (1814-1917) kak istoricheskij istochnik, Kazan 2018.

9 P. Starr, Medicine, Economy and Society in Nineteenth Century America, "Journal of Social History" 1977, no 10, p. 588-607; I. Loudon, The Nature of Provincial Medical Practice in Eighteenth Century England, "Medical History" 1985, no 20, p. 1-32; idem, Medical Care and General Practitioner, 1750-1850, Oxford 1986; P. Weindling. Medical Practice in Imperial Berlin: the Casebook of Alfred Crotjahn, "British History of Medicine" 1987, no 61, p. 391-410; A. Digby, Making a Medical Living: Doctors and Patients in the English Market for Medicine, 1720-1911, Cambridge, 1994; R. Porter, Vzglyad patsienta. Istoriya meditsiny «snizu», [in:] Bolezn" i zdorov'e: novye podhody k istorii meditsiny, ed. by Y. Shlyumbom, M. Hagner, I. Sirotkina, Saint Petersburg 2008, p. 41-72; Y. Shlyumbom, «Beremennye nahodyatsya zdes' dlya nuzhd uchebnogo zavedeniya». Bol'nitsa Gettingenskogo universiteta v seredine XVIII-XIX vekah, ibid, p. 73-103; A. Stogova, Druzheskie otnosheniya $v$ meditsinskom diskurse $v$ kontse XVI-XVII veke, "Dialog so vremenem" 2010, no 33, p. 34-58. 
also a Pole, Ivan Stanislavovich Koshtulsky, of causing the death of his children. ${ }^{10}$ Upon receiving the complaint, Vilna Medical Council conducted an investigation of the physician's expertise and treatment procedures, requested a detailed description of his interactions with patients from him.

The acquittal text of the Kowen physician allows us to analyze the behavior of patients and their relatives during the treatment, as well as their reactions to the effects of the treatment. The contextualization of the case required the restoration of the entire infrastructure of medical activities in the former Polish territories: conditions of medical education at the University of Vilnius, the level of its scientific support, the criteria for determining the epidemic danger of the territories, the pharmacy network, the level of medical culture of Polish patients, that is, everything that defined the interaction of patients with doctors.

\section{Doctor: educated or lacking knowledge}

The author of the complaint, the chief of the police in the Kowen county, was a high-ranker in the county administration - both the head of the police and a member of the lower territorial court. The county was the second largest administrative unit of the Vilna governorate. The candidate for the post of a police chief or a district chief of police was elected for three years by the local county nobility; he was subordinated directly to the governor, and through this subordination included in the system of the Ministry of Internal Affairs. The entire county (except for towns) obeyed the police chief. Here he was both a judge and a philanthropist. His responsibilities included the county inspectorate, fire safety, trade control, minor trials, paperwork management, implementing government decisions and epidemic resilience. Twice a year, he had to go through the whole county and report on its condition to the Treasury chamber and the governor. Besides these planned trips, the prison officer had to constantly travel to all the villages in order to check the state of the markets, the work of the public places, to deal with the conflicts of the residents. According to the presentation of His Majesty's Chief of Staff, Blazhevich was a zealous official. In 1827 he was awarded the Order of St. Anne, $3^{\text {rd }}$ Class.

The accused doctor, called 'Kostulski' by Blazhevich, lived a long life (1790-1868). Due to his further official service, his biography was included in the encyclopedic reference books of doctors in Poland and Russia. ${ }^{11}$ A native of the Vitebsk governorate, in 1813 he completed a course of study at the Moral and Political Department of the University of Vilna. After that, he entered the Medical Faculty of the same university and in 1818 received a Master of Medical Sciences degree there. Having acquired a medical degree in March 1820 (which, according to the Rules of Awarding Academic Degrees for Medical

10 LVIA, f. 564, ap. 1, b. 21, p. 125-125r, 184 (This file lacks the uniform pagination, and pages are bound in sheets. Thus the beginning and the end of the letter are found in the different ends of the sheet).

11 S. Kośmiński, Słownik lekarzów polskich obejmujący oprócz krótkich życiorysów lekarzy polaków oraz cudzoziemców w Polsce osiadłych, dokładną bibliografią lekarską polską od czasów najdawniejszych aż do chwili obecnej, Warszawa 1883. 
Officials of 1819, required complicated exams and a defense of a thesis), he took up private practice in Kowno.

In 1825, almost 5,000 residents lived in this second largest city in the Vilna governorate. For seven years, the young Pole treated the townspeople and villagers who engaged him. And although Koshtulsky treated all diseases, he gained special fame as an obstetrician and a gynecologist. Local women willingly called for him in all difficult cases.

The medical education at the University of Vilna was not specialized at that time. A physician could concentrate solely on surgery, obstetrics or ophthalmology only during his further practice in a big city, in a metropolitan hospital or by choosing a scientific career. Since no one knew in advance about the ways of his service, graduates of medical faculties were trained to diagnose and treat all types of diseases.

Vilna medical students were lucky to have the best teachers. At the beginning of the $19^{\text {th }}$ century, their university became one of the richest in Europe. In addition to the standard (considerable) budget for Russian imperial universities, it received funds from Polish Jesuit estates, private donations and moneyed assistance from city monasteries. ${ }^{12}$ The acquired funds allowed the professorial council to hire first-class scientists.

The Faculty of Medicine (aka Medical Department) of the University of Vilna consisted of seven departments (courses) and seven additional academic disciplines. Accordingly, seven professors gave lectures: Jacob Briote on surgery; Ivan (Jan, Johannes) Lobenwein on anatomy; Andrew Sniadecki (Jędrzej Śniadecki), the student of the Viennese Professor Johann Peter Frank (Senior) on chemistry; Augustus Benyu on pathology; Ferdinand Spitznagel on general therapy and medication; Joseph Frank (Junior) on special treatment and clinic; Joseph Matusevich on midwife art; Ludwig Heinrich Bojanus on scamotherapy (veterinary medicine); the extraordinary professor Ivan (Johannes Fridrich) Niszkowski and three associate doctors on surgery. ${ }^{13}$

While the trustees of newly opened Russian universities could not find professors to give lectures and were forced to stop teaching at the medical departments, ${ }^{14}$ academic life in Vilna carried on its two-century tradition. Therefore, in 1803, the local medical faculty awarded ten academic degrees in medicine and issued ten licenses to foreign doctors. ${ }^{15}$ All defenses of theses and awarding of scientific degrees took place according to the scenario developed from the end of the previous century.

Having received financial privileges, the Vilnius trustee Adam Czartoryski approved the proposal of the medics of Vilnius to invite renowned Austrian professors going by the surname Frank, a father and a son, to teach at the university. In January of 1804, the University Council managed to persuade J.P. Frank (1745-1821) - at that time an honorary member of the University of Vilna, the author of a multi-volume tractate on medical police, the director of the Vienna hospital, a professor of therapy and clinic - to move to Vilna. Although at that time Frank was almost 60 years old, the professors hoped he

12 LVIA, f. 720, ap. 1, b. 39, p. 229.

13 LVIA, f. 720 , ap. 1, b. 1, p. 93.

14 In 1806 the Kazan trustee S. Ya. Rumovsky wrote to Vilno that he could not get a medical professor to open the clinical department in Kazan. He asked J. Frank to help him to find anyone. (LVIA, f. 720, ap. 1, b. 1, p. 63). In 1815 the medical science department of the Kazan University graduated three medics (Istoriya Kazanskogo gosudarstvennogo meditsinskogo universiteta, ed. by V. Al'bitsky, Kazan 2006, p. 9).

15 LVIA, f. 720, ap. 1, b. 1, p. 94. 
was vigorous enough to start his life in a new place. And his name could attract medical students from different countries to Vilnius University, ${ }^{16}$ as it was in Vienna, where J.P. Frank had come from Pavia.

But the local professors were especially glad that, having invited the father, they were able to attract his son, J. Frank Junior (1771-1842), to Vilna. Of course, his father was famous, had an impeccable scientific reputation and a lot of students, but his son had a reputation of an excellent teacher of the clinic and an organizer of practical medical education. Joseph Frank spoke Latin, French, Italian, German, and English, and taught pathology, anatomy, chemistry, and pharmacy. Physicians from all over Europe came to him at the Vienna hospital and paid for their education ${ }^{17}$. Frank Jr. was also an honored scientist. He published his study guides in Latin. In addition, he had just made a long scientific trip to English and Scottish universities and hospitals, then to German and French medical centers, after which he intended to publish 'descriptions and notes about hospitals and clinics' he had examined. Upon returning to Vienna, he received an offer from the University of Padua, ${ }^{18}$ but refused it, not wanting to part with his family and old father.

In order to lure him into Vilna and outrun the competitors, the professorial council offered exceptional conditions to both Franks. Frank Sr. was offered two professorships, two salaries and a service house, as well as a guarantee that his son would inherit these departments. ${ }^{19}$ In case of an illness, half of the salary remained for him, and in the event of the death, his two daughters were provided by the Russian Emperor with 500 rubles in silver each year until marriage. ${ }^{20}$

Frank Jr. was promised the Department of Pathology and an additional course in general therapy. He was expected to help organize a medical clinic at the university. ${ }^{21}$ The professors of Vilna were well aware of the fame of Frank Sr. as the organizer of medical education in Lombardy. There, he increased the term of medicine studies to five years, created clinics for student practice, and sought (though unsuccessfully) a combination of medicine and surgery in one department. He intended to implement this plan in Vilna together with his son.

Since next year Minister of the Interior V.P. Kochubey invited Frank Sr. to St. Petersburg to reform the state medicine and the medical-surgical academy, Joseph Frank and his colleagues continued to improve medical education in Vilna. In 1805, he created the Vilna Medical Society and for twenty years he was its secretary. On his initiative, the Charity Society (1807), the Smallpox Vaccination Society (or the Vaccination Institute, 1808), the Obstetric Institute (or the Maternity Institute, 1809) arose. During the Vilna period, Frank Jr. published two major works in Latin - the works of the Medical Institute in Vilna (Acta institute clinici Caesareae universitatis Vilnensis, 1808-1812) and six volumes of practical medicine ('Praxeos medicae' universae praecepta, 1811-1824). He examined in Vilna the morbidity and mortality of the local population, revealed the relationship between a disease and the climate. After retiring in 1823, he went first to Austria and then to Italy, 
where he wrote memoirs about his life in Vilna. In 1913 they were published in Polish in Vilna. ${ }^{22}$

For nearly twenty years, Frank Jr. taught the clinical medicine to his students. He reformed the medical faculty, created a hospital there and the Medical Institute. The archive of the Medical Council of the Ministry of Internal Affairs contains quite a lot of complaints about the level of readiness of graduates of provincial universities for medical service. As for the qualification of Vilna students, the government was invariably satisfied and increased the number of its students in this school.

As it follows from the certificate of the Medical Council, Koshtulsky received a Medicine Doctor degree in Vilna University (next after a university degree). Only a student of the first department (that is, with excellent knowledge) could, after several years of practice, pass exams and defend a thesis. Having taken these circumstances into consideration, all three members of the council unanimously rejected Blazhevich's suspicions of the professional incompetence of his doctor. ${ }^{23}$

\section{Scarlet fever}

As it appears from Koshtulsky's acquittal letter, the epidemic of scarlet fever raged in Kowno that year. However, the authorities did not report this information and did not take measures to combat it. Prior to the creation of the Statistical Office in the Ministry of Internal Affairs and the provincial statistical committees subordinate to it (1835), data on the 'infectious patients' were not collected by the councils and provincial governments. At the beginning of the century, state measures to combat epidemics were triggered not by information from the field, but by orders from St. Petersburg. It was only in 1838 that medical boards for the first time began sending out a form of a register of infectious diseases to the district doctors, which became an alarm signal. ${ }^{24}$

In modern medicine, scarlet fever, from the Latin scarlatum, 'bright red color', is defined as an acute infectious disease caused by group A haemolytic streptococcus. The source of infection is a person (a sick person, a recovering patient, or an infection carrier). The transmission of the causative agent of infection occurs mainly by airborne droplets, but a contact route of infection through objects is also possible. The entrance gate for the causative agent of scarlet fever is the mucous membrane of the pharynx and the fauces. Once in a human body, streptococcus secretes a toxin that triggers a toxic-allergic reaction, the external manifestations of which are typical for a scarlet fever clinical picture - fever, general intoxication (malaise, headaches, vomiting), a sore throat and rash. Treatment for mild scarlet fever is usually provided at home. Hospital care is prescribed for severe forms, when the use of antibiotics and vitamins is necessary. In severe cases, the patient is given an infusion therapy (glucose and / or povidone solutions) to reduce the intoxication. 
Historically, scarlet fever, as a type of skin rash with fever and a sore throat, was known to ancient and Arab physicians. Its first description was presented to the Europeans by the Italian professor John Philip Ingrassias in 1553. In the $16^{\text {th }}$ and $17^{\text {th }}$ centuries, Guillaume de Baillou, Jean Cottyar Poitiers, Daniel Sennert, and Simon Scliultz wrote about scarlet fever. To refer to the disease, they used various names: Ingrassias and Sennert called it 'rossalia', Baillou - 'rubiolae', Scliultz - 'epidemic malignant purpura'. The term 'scarlet fever' was first proposed by the English doctor Thomas Sydenham in 1675 and was soon adopted by the medical community. During the $18^{\text {th }}$ century, the list of publications that included the description of scarlet fever and its epidemics was supplemented by works of such famous doctors as Huxham, Fothergill and Withering in England, Storcli and Zimmermann in Germany, De Haen in Holland, Plenciz in Austria, Rosensteiu in Sweden, Tissot in Switzerland and Benjamin Rush in the USA. ${ }^{25}$

Therefore, by the beginning of the $19^{\text {th }}$ century, scarlet fever was considered a wellknown and comprehensively studied disease. Russian physicians determined its clinic by the description given in the manual of the clinical professor Joseph Frank from Vilna. His textbook was published first in Polish, and in 1825 it was translated and published in Russian under the title General Practical Medicine.

Frank defined scarlet fever as 'initially the contagious rash that is found with fever that preceded in most cases and a throat lesion, changes the color of the skin to red, and ends with flakes on the skin, leaving patients with a risk of water disease'. ${ }^{26}$ Following his predecessors, the Vilnius professor supposed that the cause of scarlet fever was a 'special infection' ${ }^{27}$ He identified three clinical forms of scarlet fever - simple, inflammatory and typhoid. ${ }^{28}$

According to Frank, 'the simple scarlet fever hardly deserves even the name of a disease... ${ }^{29}$ and no special medical prescriptions, except for a sparing diet and bed rest for the prevention of complications. He considered the inflammatory and typhoid forms of scarlet fever as deadly and recommended his colleagues to conduct active therapy with bleeding.

During the entire Middle Ages bloodletting (injections, notches, vein dissection, leeches, 'blood sucking banks') served as the primary means of anti-inflammatory and anti-fever therapy. Belief in it rested on the ideas prevailing at the time, according to which the cause of high body temperature was overheating of the body caused by an excess of blood. Although during the New Age ideas about the causes and nature of diseases have greatly changed, ${ }^{30}$ bloodletting remained among the leading methods

25 J.D. Rolleston, The history of Scarlet Fever, "British Medical Journal" 1928, no 2, p. 926-929.

26 Vseobshhaya prakticheskaya meditsina, izdannaya losifom Frankom... professorom chastnoi terapii $i$ kliniki pri Imperatorskom Vilenskom universitete... perevedennaya s latinskogo yazyka studentom Imperatorskoi Mediko-hirurgicheskoi akademii Moskovskogo otdeleniya Mihailom Matveevskim. Obozrenie predmetov, soderzhashhihsya v Pervoi chasti vo Vtoroi knige Vseobshhei prakticheskoi meditsiny, Moscow 1825, p. 216 (hereafter - J. Frank, op. cit.).

27 J. Frank, op. cit., p. 229.

28 The simple form is corresponding to the scarlatina simplex, inflammatory - to the septic, and typhoid - to the toxic fever.

29 Ibid., p. 249-250.

30 V. Stepin, A. Stochik, S. Zatravkin, Istoriya i filosofiya meditsiny: nauchnye revolyutsii XVII-XIX vekov. Moscow 2017. 
of treating inflammation and fevers even in the $19^{\text {th }}$ century. They were appointed with such consistency and with such perseverance that the patients' blood literally flowed like a river. It is estimated that only in 1800 about 85 thousand liters of blood were released in Paris hospitals, and 33 million leeches were imported to France in $1824 .^{31}$ The famous Parisian doctor F. Broussais was said to shed more French blood than all the wars of Napoleon. The apologists of the German humoral pathology were not far behind the advocates of the teachings of $\mathrm{F}$. Broussais.

Clinicians, of course, noticed that in most cases this method of treatment did not give any positive effect and the condition of patients often worsened because of this. However, the conviction of the need to 'distract' blood at any cost made it necessary to associate failures with an insufficient amount of 'bleeding blood' and prescribe additional procedures. The perseverance with which doctors sought to 'bleed' at any cost is demonstrated in the history of the treatment of cholera in the period of $1830 \mathrm{~s}-1850 \mathrm{~s}^{32}$. In the dehydrated body of a patient with cholera, the blood coagulated directly in the open vein. This fact was noted in special literature, but only to recommend colleagues to open 'large veins.' And in 1831, when this murderous recommendation proved its perniciousness, I. Dieffenbach began to inject patients a catheter through the brachial artery into the left ventricle. ${ }^{33}$

Along with bleeding, the leading role in the treatment of severe forms of scarlet fever was given to laxatives and emetics to remove 'damaged moisture.' In addition, Frank recommended to ease the painful condition of patients with scarlet fever: cold washing or affusion 'to take the heat', to make poultices and drink warm broths to facilitate the 'toad' (suffocation); for the care of the pharynx and oral cavity - to give liqueur from sage leaves with drops of hydrochloric acid and honey and a number of other liqueurs, infusions and decoctions. In case of necrosis of the pharynx, it was prescribed to use rich decoction of 'cinchona' with 'acid'. ${ }^{34}$

When it was typhoid scarlet fever, Frank recommended bloodletting in combination with stimulant and diaphoretic drugs - acetic acid ammonia, succinic acid ammonia, ammonia carbonate, camphor, wine. He paid special attention to the prevention of infection: the isolation of patients, the use of sneezing and mouth rinsing with an aqueous solution of ammonium or mineral acids were required. For disinfecting the premises, the Vilnius professor recommended the use of fumigation, 'produced either with simple or oxidized hydrochloric acid, or with nitrate acid.' Referring to the authority of the founder of homeopathy, S. Hannemann, Frank advised to use the 'condensed juice of the beauty herb' (belladonna, or deadly nightshade). In addition, he recommended making scarlet fever vaccines to healthy children. ${ }^{35}$

31 H. Vul'f, Istoriya razvitiya klinicheskogo myshleniya, "Mezhdunarodnyj zhurnal meditsinskoj praktiki" 2005, no 1, p. 12-20.

32 A. Stochik, S. Zatravkin, $K$ istorii izucheniya patogeneza i poiska sredstv lecheniya holery (po materialam pervyh treh pandemii 1817-1862 gg.), "Terapevticheskii arhiv" vol. 67, 1995, no 7, p. 75-79.

33 N. Howard-Jones, The scientific background of the International Sanitary Conferences, 1851-1938, Geneva 1975.

34 J. Frank, op. cit., p. 255

35 Ibid., 257 


\section{Treatment}

What did the family doctor face in Blazhevich's house? How was the situation predetermined? Could another doctor save the children? Now these questions lie not in the plane of medicine, but in the history of science and intellectual history.

'They [the children],' the father was indignant, 'had undamaged perfect health before. ${ }^{36}$ Blazhevich questioned the correctness of the algorithm for the treatment of scarlet fever, which was proposed by the doctor.

If we consider the actions of Dr. Koshtulsky based on contemporary views and recommendations, he could not be blamed for the death of Blazhevich's son. From the descriptions presented in the council it follows that the young man had a severe septic form of the disease, which began with fever, tonsillitis, swollen lymph nodes, and vomiting. Keeping in mind the arsenal of medical remedies available to the doctor of the first half of the $19^{\text {th }}$ century, Koshtulsky did not have the opportunity to save the patient. In his text there was not a word about the actions to care for the throat and oral cavity. These measures would not have saved the boy, but could have alleviated his sufferings.

Of the entire range of tools and medical manipulations recommended by Frank, Koshtulsky confined himself to the use of leeches, laxatives, and compound medicinal mixtures.

In medicine of the beginning of the $19^{\text {th }}$ century, drug therapy was widely used. Judging by the pharmacopeias of that time, there were hundreds of 'simple' medicines and thousands of 'complex' medicines in the arsenal of doctors. However, their ability to influence the course of disease processes was weak. Quite often the use of such medicines brought more harm than good to the sick. ${ }^{37}$

According to modern pharmacologists, most of the medications used in the $18^{\text {th }}$ - first half of the $19^{\text {th }}$ centuries did not contain active principles and, at best, had a psychotherapeutic effect. There were several dozen of drugs that actually contained bioactive components (quina, digitalis, opium, etc.). In most cases, these drugs were used either inappropriately or in the wrong dosage. This was the case with quina tree and opium bark used in the $17^{\text {th }}$ century. Observing the anesthetic and soporific effect of opium, doctors widely used it to treat heart disease, numerous asthenia, 'typhoid', etc. At the beginning of the $19^{\text {th }}$ century the Prussian physician $\mathrm{H}$. Hufeland told students that thousands of patients were victims of their physicians, too prone to prescribe opium. ${ }^{38}$

Even worse was the situation with the use of plants and minerals with a pronounced toxic effect (henbane, ergot, hellebore; compounds of mercury, lead, copper, arsenic, phosphorus, sulfur, antimony; drugs based on sulfuric or hydrochloric acid). After their introduction into the body, severe symptoms of poisoning were observed - salivation, lacrimation, vomiting, diarrhea, various lesions of the central nervous system. Doctors, guided by traditional ideas about diseases, after observing these reactions in patients

36 LVIA, f. 564, ap. 1, b. 21, p. 125-125r, 184.

37 A. Stochik, S. Zatravkin, Ot klassifikatsionnoi meditsiny k meditsine klinicheskoi (konets XVIII v. - 70-e gg. XIX v.). Soobshenie 5. Reformirovanie lechebnogo dela v 40- $h$ - 60-h gg. XIX veka, "Terapevticheskii arhiv" 2012, no 1, p. 69-73.

38 W. Ameke. Die Entstehung und Bekämpfung der Homöopathie. Mit einem Anhang: Die heutige UniversitätsMedicin, Berlin 1884. 
interpreted them as signs of recovery - 'signs of the disease getting out of the body'. ${ }^{39}$ In an effort to achieve this effect, doctors prescribed toxic substances in large doses and thus often killed patients earlier than the disease itself.

At the period under investigation doctors rarely prescribed medicines which consisted of one ingredient (simple medicines). Complex compositions of eight to ten or more components were usually prescribed..$^{40}$ 'When I started practicing,' the famous English internist T. K. Albatt wrote about the events of the mid-1830s, 'it was customary for the days of consultations to prepare a desk, feathers, inkpoints for writing out prescriptions

- these monumental works. For each symptom, a specific medication was prescribed and several supplements for the disease as a whole.' As preserved disease histories indicate, in acute 'transient' diseases, prescriptions were changed every day, and in case of chronic diseases, every $2-3$ days. ${ }^{41}$

Kostulsky treated the children from Kowen similarly. In the text of his acquittal letter, he meticulously listed and attached to the document all the prescriptions he had written. Obviously, they were supposed to serve as evidence of his conscientious work and as the means to earn the respect of the parents.

\section{Pharmacies and drugs}

The text by Koshtulsky mentions at least six complex drugs and two potions with herbal ingredients, for which there are prescriptions recorded in the pharmacist's journal. In addition, the mother of the sick children bought 90 leeches on the recommendation of the doctor and some more independently. The children were watered with solutions of belladonna, elderberry, they were given rhubarb.

All these medicines were purchased at a local pharmacy. In total, there were two of them in Kowno - Fischer's and Ley's. Koshtulsky preferred to cooperate with the latter. In Russia the prescribed medications were prepared by owners of free pharmacies according to the Russian Pharmacopeia, ordered by Catherine II and created by one of the members of the Medical College, Professor N.K. Karpinsky. ${ }^{42}$ In describing the composition and technology of drug manufacturing, the author focused on the resources of the Russian state - its natural resources and import purchases. State-owned and freestanding pharmacies of the Russian Empire purchased medicinal materials in pharmacy

39 J. Theden. Kratkie nastavlenia vo vrachebnoi nauke, ili Kratkii sistematicheskii kurs meditsiny: Karmannaya kniga, Moscow 1835.

40 In the $18^{\text {th }}$ and first half of the $19^{\text {th }}$ century the most popular "purification" therapy drug was the recipe including Alexandrian senna, spiritus vini, lion's tooth, rhubarb, salammoniac, Elytrigia, mercury and antimonium.

41 W. Ameke, op. cit.

42 The creation of Russian Pharmacopeia was ordered to the Medical Council by the government as early as in 1763. The task was to free Russian market from the dependence upon the import. The analogues of the Western drugs that could be prepared from Russian herbs and other ingredients. Karpinsky fulfilled the order and issued the two-volume «Pharmacopoeia Rossica» in 1788, then it was translated to Russian in 1802 by I. Leontovich, then the medical student in the Moscow University: Rossiiskaya farmakopeya ili apteka s podrobnym i yasnym nastavleniem, nauchayushhim, $v$ kakom vide $i$ kolichestve luchshe $i$ poleznee kak $i$ vnutr', tak i snaruzhi upotreblyat' lekarstva, kak-to: razlichnye poroshki, kapli spirtnye i pr., transl. by I. Leontovich, Moscow 1802. 
stores, ${ }^{43}$ and their storerooms were replenished with pharmaceutical gardens and import purchases. ${ }^{44}$ In 1814, the Medical Council divided all medicinal substances entering pharmacies into two categories: medicinal and poisonous. Medicinal herbs and minerals not included in the two published catalogues could be sold not only in pharmacies, but also in oilery and green shops. ${ }^{45}$

The treatment by scientists-doctors was not cheap. In addition to having to pay for the arrival of the doctor himself, the medicines prescribed by him were expensive. In the $18^{\text {th }}$ century, their cost was arbitrarily determined by pharmacists, depending on the financial capabilities of patients. But in 1789 the first Pharmacy Charter appeared in the Empire, introducing pharmacy taxes (state-controlled drug pricing). These books with columns of Latin names of ingredients and fixed prices for them were on the tables of all pharmacists, and the medical board pledged to ensure that pharmacy owners did not overstate them. In addition, the Ministry of the Interior Affairs introduced rules for sale and transportation of medicines, indicating the time of getting the prescription at the pharmacy and the time of manufacture of medicines (1808). ${ }^{46}$ Obviously, the constant change of drugs cost the Blazhevich family a considerable sum of money.

\section{Confidence}

Exploring the materials of the British medical archives, Anna Digby concluded that patients who bought medical services in Victorian England had a vague idea what they were acquiring and therefore had to trust the knowledge or art of their doctor. ${ }^{47}$ Perhaps it did not always happen to everyone. And although the situation with the wide use of medical services in England and the Vilna governorate was more similar than between Vilna and Voronezh governorates, the whole text by Koshtulsky was testimony to Mrs. Blazhevich's growing distrust of the doctor's actions.

Obviously, the spouse of the district police officer was a resolute and distrustful lady, and perhaps the circumstances of mortal danger and fear made her become such a woman. When Koshtulsky came to the Blazhevich's for the first time, he learned that the mother of the sick boy had already begun his treatment. For stomach pains, she gave him rhubarb tincture. The doctor considered it a mistake. Obviously, he blamed Blazhevich for arbitrariness, frightened her, and explained why the boy should have been given the emetic, and not the laxative. After that, for several days, the woman was a faithful performer of the will of the family doctor. She obediently followed all his prescriptions, smoothly paid for expensive medicines, hid unnecessary ones, ordered new

43 Pharmacy store is a merchandise, that choose the trade license of the 2 nd grade. They could be opened on the usual terms. They sell raw and processed pharmacy goods, also the perfumery products, etc. They do not have the right to prepare and sell prescribed and prepared drugs; equally, the retail trade of the pharmacy goods is prohibited. First violation leads to the money penalty of 25 roubles, second to 50 , third cancels the license.

44 The statement on the permission to deliver different foreign products 1816 («Manifest o razreshenii privoza raznyh inostrannyh tovarov 1816»), Saint Petersburg 1816, p. 7.

45 Complete Collection of Laws of the Russian Empire [Polnoe sobranie zakonov Rossiiskoi Imperii], coll. 1, vol. XXXII, no 25664, p. 897-902.

46 Complete Collection of Laws of the Russian Empire, coll. 1, vol. XXX, no 22739, p. 4.

47 A. Digby, op. cit., p. 3. 
ones, limited children to food, forced them to drink bitter drinks and swallow horrible medicines, observed wriggling leeches which were put on the throat of her five-year-old girl and eleven-year-old boy.

However, as their condition rapidly deteriorated, her despair and distrust of the family doctor's knowledge and manipulation grew. She hardly read Joseph Frank's Practical Medical Tips, but she probably discussed the cases of children's scarlet fever with other Kowno residents. She seemed to trust her intuition and children's reactions to the measures taken more than the doctor, so she persuaded the doctor to repeat the measures that gave at least some relief. ${ }^{48}$ That is, the doctor had to overcome the resistance of the mother and to achieve her obedience with great difficulty.

A few days after the first call, the situation at the Blazhevich's became out of control of the doctor. In contrast to the part-time doctor, the mother of the children who were rushing around deliriously was constantly around them, saw the deterioration and suffered from her own helplessness. She stopped waiting for help from the outside and tried everything, including putting leeches. ${ }^{49}$ From the experience of previously observed treatments, analyzing the reaction of the children to medications and even the experience of family recovery, she drew her own conclusions, made analogies and more and more decisively intervened in the treatment. ${ }^{50}$ In the end, the woman decided to take an extreme measure - to treat children herself with 'good' medicines, which once helped to recover her mother. ${ }^{51}$ Apparently, expensive drugs were not thrown away after they were used and cured, they were kept in the house just in case.

Thus, there unfolded the struggle of medical knowledge at the bed of the mortally ill children.

After the children left this life, the district police officer accused the family doctor of the lack of necessary knowledge for the treatment of scarlet fever, deceiving the trust of patients. A man of state service, he believed in the state and its ability to identify and absorb the best people. A private practitioner was in his view a person who did not receive or was deprived of a government position. Most likely, such a physician could not find a 'place' due to the lack of talent and zeal. In his view, county and military doctors had more information and were more experienced than a private doctor. ${ }^{52}$ Apparently, if he were down to him, he would have used the services of the county doctor Kovalsky or the military doctors who had arrived then in Kowna. However, the wife had piously believed in her healer before this misfortune.

Koshtulsky testified that he had treated all the members of the Blazhevich family for five years, cured his spouse of a chronic disease and was the 'guardian angel' of this house. ${ }^{53}$ He mentioned other doctors and competitors slandering him. In addition, the scholarly doctor accused parents of arbitrariness. He began the letter with the description of the family drama that preceded the boy's illness. Referring to the mother's testimony, Koshtulsky believed that the angry father's decision to send him to school during the 
epidemic and the tough educational conversation with him about his success in school hurt the boy's health. ${ }^{54}$ Only a strong weakness of the child aggravated the parents and prompted the mother to break the will of her husband - to leave her son at home. Koshtulsky told his colleagues how the mother resisted the treatment and used quack knowledge. ${ }^{55}$

\section{Professional solidarity}

After reading the chronicle of the treatment and death of Blazhevich's children, the experienced doctors of the Vilna Medical Board could not help but notice the mistake of their colleague that contributed to the death of the younger child. The family doctor did not require parents to isolate the sick child from the family members. Frank's guide made this very clear. Meanwhile, in the acquittal of Koshtulsky there was no mention of home quarantine, but there was expressed discontent that the mother had kept the sick boy and his sister in the room with drafts. This led, in his opinion, to the complication of a cold.

The members of the medical board acquitted Koshtulsky, admitted that the treatment had been carried out correctly and only advised him next time to be careful when prescribing the number of leeches. They should be put more, not less. ${ }^{56}$

In the expert opinion not a word was said about the lost girl and her treatment. Why? We can only make assumptions. Blazhevich appealed to the council as a public person to a public institution for the punishment of a private doctor. The epoch was quite favorable for it. During the reign of Nikolay I, the government clearly demonstrated the priority of public service over all other employment. However, the district police officer did not find any solidarity in the members of the medical board on the principle of state service.

From our point of view, the main reason for the loyalty of the members of the administration to the evaluation of the medical practice of the private doctor was the fact that Kostulsky quite often rescued its members, who were overwhelmed with a pile of official instructions. Judging by the archival evidence, the inspector of the council often involved in the carrying out state orders private practitioners, who were not obliged to do this and did not get anything for their services. Unlike other colleagues, Koshtulsky was a reliable assistant to the district doctor and the executor of the instructions of the administration. He often went to 'infectious' villages instead of Kovalsky.

In addition, the members of the council were guided by respect for the academic title of Koshtulsky. Infant mortality from scarlet fever was so high (up to $60 \%$ of ill children died) that the case of another death could not be directly dependent on the knowledge of the doctor. In the end, the only son of Joseph Frank, Victor, also died from this disease and his father's extensive knowledge could not save him. ${ }^{57}$ In addition, at the moment of great danger to the lives of the children, Kostulsky held a consultation with the county 
doctor, Kowalski. ${ }^{58}$ After that, the lethal outcome of the treatment became the collective responsibility of the medical community of Kowno, including the state doctor. Revealing his mistake and pointing out its connection with the child's life meant making the medical practice controlled by patients, undermining the residents' trust in scientific medicine in general, in its degrees and titles, and losing power over non-medical people.

Koshtulsky was acquitted by his colleagues, but he either suffered or simply knew that, because of the influence of the Blazhevichs and their accusations, he no longer had a place in Kowno and the Kowno district. If only Blazhevich did not exaggerate and did not intimidate the medical board, then he assured that the residents of Kowno sympathized with the grief of the well-known family and blamed not the scarlet fever epidemic, but the doctor for the children 's death: 'Kostulsky is grumbled in many places'. ${ }^{59}$

The private doctor applied to the Emperor for the permission to enter public service. The request was granted, and on 14 September 1828, he left the city for Warsaw as an obstetrician. Stanislav Rosolowski became a private practitioner in Kowno instead. ${ }^{60}$ In the Kingdom of Poland Koshtulsky`s career flourished without complications. A few years later he became a member of the medical council, in the 1840s he published a number of scientific articles in Polish and in 1863 he successfully retired.

So, what does the unique document show about the treatment of Blazhevich's children? What phenomena of social and intellectual history did it record?

Apparently, in the first third of the $19^{\text {th }}$ century, in the Vilna governorate, there remained the system of private scientific medicine inherited from the Polish-Lithuanian Commonwealth, the practice of protecting the health by domestic and landowner doctors. The Russian Empire imposed a network of unified state administrative medicine on the culturally and economically different regions. But until the 1830s, state-owned ('Russian', although most of them were either Poles or foreigners in the Russian service) and private ('Polish') physicians acted autonomously, performing different functions some solved managerial problems, others treated the inhabitants. The incident described above became the field where their interests intersected: both the members of the medical board and the private doctor faced the aggression of the patients who had lost faith in the magic of their scientists. This situation generated professional solidarity to the detriment of bureaucratic solidarity.

The incident in Kowen indicates that in the 1820s, at the western borders of the Empire, medical knowledge came out of a narrow professional field and was assimilated / appropriated by patients, allowing them to establish their own control over medical practice. Polish patients shared the friendly British style of communication with a doctor, ${ }^{61}$ but the deadly danger put limits on this familiarity.

In this situation of helplessness in the face of the imminent death of the children, their mother lost her former faith in the ability of the family doctor to protect them from harm. The ability to pay for medical services did not protect the family from the danger of contagious diseases. Observing the ineffectiveness of the treatment, Blazhevich used her 
own medical knowledge. It was not alternative scientific medicine. The woman did not rush to the priest or a folk healer. Trusting in the ability of the doctor to save her children, she tried to save them with his own knowledge, transferred to her before, and medicines of scientific medicine. Even her husband appealed to the colleagues of Koshtulsky - scientists, doctors of the state medical board. In this regard, residents of the Vilna governorate were in contrast with the inhabitants of the inner regions of the Russian Empire.

\section{Bibliography}

\section{Archival sources}

Lithuanian State Historical Archive, Vilnius (Lietuvos valstybès istorijos archyvas) [LVIA], f. 564 , ap. 1, b. 21 , 58; f. 720, ap. 1, b. 1, 39; f. 721, ap. 1, b. 383.

Russian State Historical Archive, St Petersburg (Rossiyskiy gosudarstvenniy istoricheskiy arkhiv) Petersburg [RGIA], f. 745, op. 3, d. 8, p. 5r.

\section{Printed sources}

Ameke W. Die Entstehung und Bekämpfung der Homöopathie. Mit einem Anhang: Die heutige Universitäts-Medicin, Berlin 1884.

Complete Collection of Laws of the Russian Empire [Polnoe sobranie zakonov Rossiiskoi Imperii], coll. 1, vol. XXXII, no 25664.

Complete Collection of Laws of the Russian Empire [Polnoe sobranie zakonov Rossiiskoi Imperii], coll. 1, vol. XXX, no 22739.

Frank J., Pamiętniki D-ra Józefa Franka, Profesora Uniwersytetu Wileńskiego, transl. by W. Zahorski, vol. 1-3, Wilno 1913.

Manifest o razreshenii privoza raznyh inostrannyh tovarov 1816, Saint Petersburg 1816.

Rossiiskaya farmakopeya ili apteka s podrobnym i yasnym nastavleniem, nauchayushhim, v kakom vide $i$ kolichestve luchshe i poleznee kak i vnutr', tak i snaruzhi upotreblyat' lekarstva, kak-to: razlichnye poroshki, kapli spirtnye i pr., transl. by I. Leontovich, Moscow 1802.

Theden J.C.A., Kratkie nastavlenia vo vrachebnoi nauke, ili Kratkii sistematicheskii kurs meditsiny: Karmannaya kniga, Moscow 1835.

Vseobshhaya prakticheskaya meditsina, izdannaya losifom Frankom... professorom chastnoi terapii i kliniki pri Imperatorskom Vilenskom universitete... perevedennaya s latinskogo yazyka studentom Imperatorskoi Mediko-hirurgicheskoi akademii Moskovskogo otdeleniya Mihailom Matveevskim. Obozrenie predmetov, soderzhashhihsya v Pervoi chasti vo Vtoroi knige Vseobshhei prakticheskoi meditsiny, Moscow 1825.

\section{Critical literature}

Digby A., Making a Medical Living: Doctors and Patients in the English Market for Medicine, 1720-1911, Cambridge 1994.

Gatina Z., Gde iskat' dissertatsionnye dela russkih vrachei, ili Osobennosti arhivirovaniya deloproizvodstva meditsinskih fakul'tetov, [in:] Biografii universitetskih arhivov, ed. by E. Vishlenkova, V. Parsamov, K. Ilina, Moscow 2011, p. 102-113. 
Howard-Jones N., The scientific background of the International Sanitary Conferences, 1851-1938, Geneva 1975.

Ivanova R., Protokoly zasedanij meditsinskogo fakul'teta Kazanskogo universiteta (1814-1917) kak istoricheskij istochnik, Kazan 2018.

Kośmiński S., Słownik lekarzów polskich obejmujący oprócz krótkich życiorysów lekarzy polaków oraz cudzoziemców w Polsce osiadłych, dokładną bibliografią lekarską polską od czasów najdawniejszych aż do chwili obecnej, Warszawa 1883.

Lane J., A Social History of Medicine. Health, healing and disease in England, 17501950, London, New York 2001.

Loudon I., Medical Care and General Practitioner, 1750-1850, Oxford 1986.

Loudon I., The Nature of Provincial Medical Practice in Eighteenth Century England, "Medical History" 1985, no 20, p. 1-32.

Porter R., Vzglyad patsienta. Istoriya meditsiny «snizu», [in:] Bolezn' i zdorov'e: novye podhody $k$ istorii meditsiny, ed. by Y. Shlyumbom, M. Hagner, I. Sirotkina, Saint Petersburg 2008, p. 41-72.

Rolleston J.D., The history of Scarlet Fever, "British Medical Journal" 1928, no 2, p. 926-929.

Sambuk D., Wächter der Gesundheit. Staat und lokale Gesellschaften beim Aufbau des Medizinalwesens im Russischen Reich 1762-1831, Köln 2015.

Shlyumbom Y., «Beremennye nahodyatsya zdes' dlya nuzhd uchebnogo zavedeniya». Bol'nitsa Gettingenskogo universiteta v seredine XVIII-XIX vekah, [in:] Bolezn' i zdorov'e: novye podhody $k$ istorii meditsiny, ed. by Y. Shlyumbom, M. Hagner, I. Sirotkina, Saint Petersburg 2008, p. 73-103.

Starr, Medicine, Economy and Society in Nineteenth Century America, "Journal of Social History" 1977, no 10, p. 588-607.

Stepin V., Stochik A., Zatravkin S., Istoriya $i$ filosofiya meditsiny: nauchnye revolyutsii XVII-XIX vekov. Moscow 2017.

Stochik A., Zatravkin S., $K$ istorii izucheniya patogeneza i poiska sredstv lecheniya holery (po materialam pervyh treh pandemii 1817-1862 gg.), "Terapevticheskii arhiv" vol. 67, 1995, no 7, p. 75-79.

Stochik A., Zatravkin S., Ot klassifikatsionnoi meditsiny $k$ meditsine klinicheskoi (konets XVIII v. - 70-e gg. XIX v.). Soobshenie 5. Reformirovanie lechebnogo dela v 40- $h-$ 60-h gg. XIX veka, "Terapevticheskii arhiv" 2012, no 1, p. 69-73.

Stogova A., Druzheskie otnosheniya v meditsinskom diskurse v kontse XVI-XVII veke, "Dialog so vremenem" 2010, no 33, p. 34-58.

Vishlenkova E., Mediko-biologicheskie ob"yasneniya sotsial'nyh problem Rossii (vtoraya tret' XIX veka), [in:] Istoriya i istoricheskaya pamyat': Mezhvuz. sb. nauch. tr., vol. 4, ed. by A. Gladyshev, Saratov 2011, p. 37-66.

Vishlenkova E., The State of Health: Balancing Power, Resources, and Expertise and the Birth of the Medical Profession in the Russian Empire, "Ab Imperio" 2016, no 3, p. 39-75.

Vul'f H., Istoriya razvitiya klinicheskogo myshleniya, "Mezhdunarodnyj zhurnal meditsinskoj praktiki" 2005, no 1, p. 12-20.

Weindling P. Medical Practice in Imperial Berlin: the Casebook of Alfred Crotjahn, "British History of Medicine" 1987, no 61, p. 391-410. 
Zatravkin S., Shepin V., Oleinikova V., Obespechennost' vrachami naseleniya Rossiiskoi Imperii v XIX - nachale XX veka, "Problemy sotsial'noj gigieny, zdravoohraneniya i istorii meditsiny" 2017, no 4, p. 236-239.

\section{Funding}

The article was prepared within the project № 19-48-04110 supported by Russian Science Foundation.

Elena Vishlenkova, Doctor of Science in History, Professor of the History Department and Head Researcher of the A. Poletaev Institute for Theoretical and Historical Studies in the Humanities (IGITI), National Research University Higher School of Economics (Moscow, Russian Federation). E-mail: evishlenkova@mail.ru

Sergei Zatravkin, Doctor of Science in Medicine, Professor of the History of Medicine, Head of the Department of the History of Medicine; Semashko' Institute of Public Health (Moscow, Russian Federation) and Head Researcher of the A. Poletaev Institute for Theoretical and Historical Studies in the Humanities (IGITI), National Research University Higher School of Economics (Moscow, Russian Federation). E-mail: zatravkine@mail.ru

Article submitted on 16 October 2018

Article accepted on 10 February 2019

\section{Polska medycyna w Cesarstwie Rosyjskim w pierwszym trzydziestoleciu XIX w.}

Skarga urzędnika na polskiego prywatnego lekarza, który leczył jego dzieci na szkarlatynę w 1827 r., zaowocowała powstaniem niepowtarzalnego dokumentu - opisu procesu leczenia oraz kontaktów lekarza z pacjentami, farmaceutami i władzami rosyjskimi. W rosyjskich archiwach rzadko można natrafić na takie świadectwo. Ponieważ prywatni lekarze nie odpowiadali przed urzędnikami, ich świadectwa, co do zasady, nie są przechowywane w państwowych archiwach. Tekst odnaleziony w archiwum Wileńskiej Rady Lekarskiej zachęcił autorów niniejszego artykułu do zbadania stanu opieki i kultury medycznej wśród Polaków, którzy znaleźli się w Cesarstwie Rosyjskim po trzecim rozbiorze Rzeczypospolitej. Wiszlenkowa i Zatrawkin ustalili, że - inaczej niż w pozostałej części Cesarstwa - dość gęsta sieć prywatnej opieki medycznej istniała w guberni wileńskiej do lat trzydziestych XIX w., a poziom naukowej kultury medycznej wśród pacjentów umożliwiał im kontrolowanie przebiegu leczenia. 